\title{
A COMPARATIVE REVIEW ON COMPANY SPECIFIC DETERMINANTS FOR SUSTAINABILITY REPORTING IN UNITED KINGDOM (UK) AND MALAYSIA
}

\author{
Xue Fa Tong* \\ Faculty of Business, Multimedia University Melaka
}

\begin{abstract}
This study aims to comparatively assess the effects of company-specific variables on the level of corporate social responsibility (CSR) information disclosed in publicly-traded companies from United Kingdom (UK) and Malaysia. Content analysis was applied to sampled reports from the FTSE 100 Index and FTSE Bursa KLCI against inferred meanings from the Global Reporting Initiative (GRI)-derived coding base to identify similarities and/or differences in CSR disclosure practices. The Spearman's correlation coefficients and multiple linear regressions (MLR) analyses further gauged the associations between the variables and total quantity of CSR disclosure (TQCSR); and, determined the predictive determinants on sustainability reporting.

The Spearman's correlation has identified a negative association on leverage with TQCSR for UK companies. In contrast, the TQCSR in the Malaysian sample was positively associated with directors' CSR-related experiences and profitability but negatively associated with company size. Results from MLR analyses presented company size as a significant determinant on sustainability reporting in the UK model, while directors' experiences were indicated as the crucial determinant in the Malaysian model. This first, direct cross-market sustainability reporting study highlights the importance of board of directors' CSR-relevant experience in influencing the level of CSR disclosures in publicly-traded companies.
\end{abstract}

Keywords: Sustainability reporting, Global Reporting Initiative (GRI), corporate social responsibility (CSR), board experience

\section{INTRODUCTION}

Sustainability reporting has emerged as a powerful tool in gaining long term business growth and competitive advantage. The practice to report high quality non-financial data beyond the financial bottom line helps companies to mitigate potentially material financial impact of environmental and social risk in their businesses. In May 2013, the non-mandatory G4 Sustainability Reporting Guidelines was initiated to commensurate the need for a more relevant, transparent and credible integration of sustainability indicators into sustainability reporting practices. Although the G4 framework is a useful reference in homogenising corporate social responsibility (CSR) disclosures across global market sectors, many sustainable reports are still inconsistent and reactive in nature (Jagd, 2015; Fortainer et al., 2011; PwC's Sustainability Reporting, 2008). The inconsistency in levels of non-financial CSR disclosures is predicated on the polarizing prioritisation of the "stakeholder versus shareholder" approaches in addressing societal issues (Freeman and Moutchnik, 2013), the 
cost of disclosing information voluntarily (Gamerschlag et al., 2011; Kytle and Ruggie, 2005; LaFond and Watts, 2008), and, the varying interpretations of the recommended guidelines.

This study intends to juxtapose the sustainability reporting agenda of publicly-traded companies from the United Kingdom (UK) and Malaysia. While there are substantial empirical researches on the determinants of CSR disclosure practice internationally, crossmarket comparison on sustainability reporting activities were scarce and mainly explored the macro-effect of country-level variables and political-legal systems (Ioannou and Serafeim, 2016; Anderson and Gupta, 2009; La Porta et al., 2008). Furthermore, only a few studies on CSR determinants were relevant to the Malaysian context (Mat Nor, 2010; Amran et al., 2007). In order to better understand the readiness of Malaysian companies in pursuing the CSR agenda, a comprehensive comparative study against a developed CSR reporting regime such as the UK is necessary.

For these reasons, the aim of this study is to critically analyse and identify the key drivers for sustainability reporting of the top 30 publicly-traded companies in the UK and Malaysia. This paper extends prior research on the effect of company-level determinants in explaining voluntary CSR disclosure practices (Lan, et al., 2013; Gamerschlag et al., 2011). The study will address two fundamental research questions:

1) What are the company-specific characteristics associated with corporate social responsibility (CSR) disclosures?

2) What are the specific variables predicting the amount of CSR-related information disclosed in the sustainability reports for each country?

Data collected from publicly traded companies operating in the FTSE 100 Index and FTSE Bursa Malaysia KLCI will be subjected to in-depth two-phase analyses to corroborate and quantify the developed hypotheses. Withstanding industry classifications, the research expects a strong positive correlation to exist between the identified internal company-specific drivers (i.e. board experience, profitability, financial leverage) and the level of CSR disclosures in sustainability reporting for both countries regardless of potential cross-market differences. Findings from the study will contribute to a greater understanding on the varying degree of sustainability reporting practices in companies and progress the dimension on CSRreporting literatures.

\section{LITERATURE REVIEW}

The Global Reporting Initiative (GRI) describes sustainable reporting as a form of comparable non-financial reporting, which communicates sustainability-related information on economic, environmental, social and governance performance of a corporation or organisation. On account of a non-existing 'one size fits all' framework, marked variations in the level of CSR disclosures was observed within the Malaysian sustainability reporting practices, which were behind that of in the UK (UNEP, 2013; Chambers et al., 2003). Despite the increased CSR awareness among Malaysian companies and noteworthy efforts to go beyond the standard industry and Bursa Malaysia reporting requirements, the quality of CSR disclosures within Malaysian annual reports is dismal to the normal scope of corporate financial reporting (MaSRA, 2013). Previous studies have suggested the importance of company-specific characteristics as proxies in inducing their disposition and responsiveness in disclosing additional CSR information voluntarily (Lan et al., 2013; Gamerschlag et al., 2011; Siegel and Vitaliano, 2007; Orlitzky et al., 2003). 
Thus, this study seeks to determine the pre-existing influence of company-level variables on the level of sustainability reporting preceding the transitional implementation period of the G4 Sustainability Reporting Guidelines in 2014 and 2015. In addressing the internal organisational factors of sustainability reporting, extensive literature search indicated dearth of quantified measures on board experience as an antecedent to CSR disclosure levels. This research proposes to establish the role of board of directors with CSR-relevant experiences as a new empirically measurable variable in sustainability reporting. Figure 1 illustrates the identified determinants of sustainability reporting tested in this study.

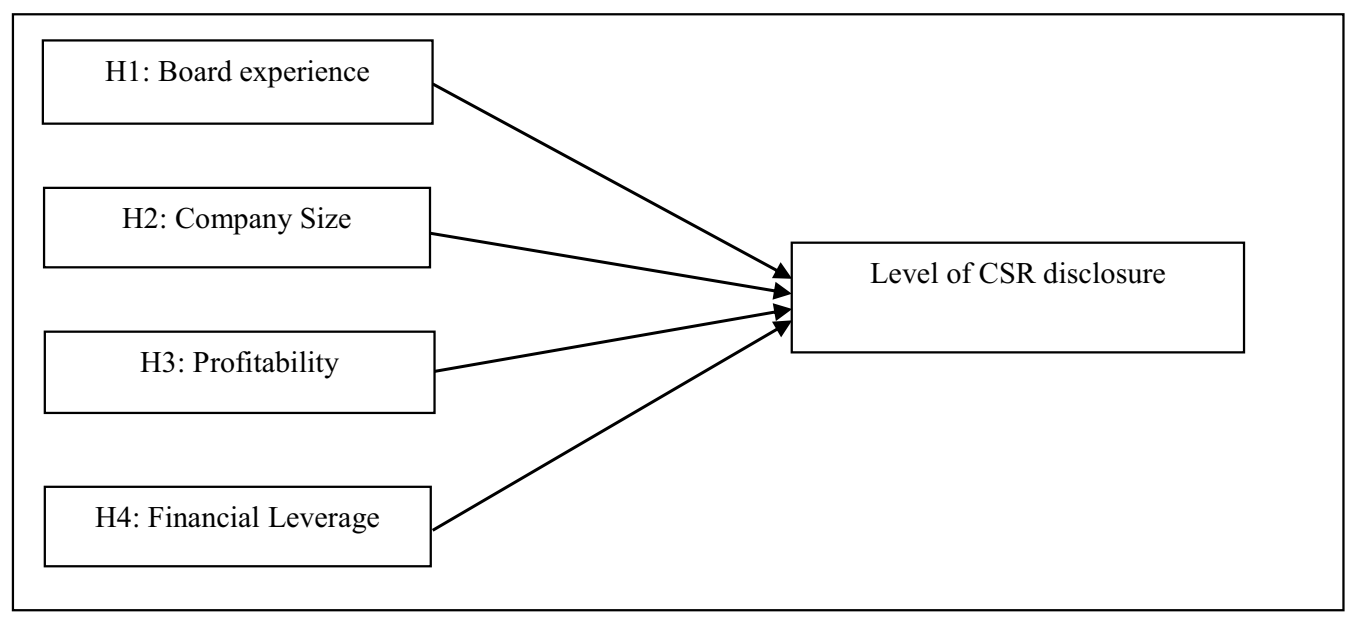

Figure 1: Framework of determinants of CSR disclosure in sustainability reporting

\section{Board experience}

Both the UK Financial Reporting Council and Securities Commission Malaysia recommends the composition of the board and its committees to comprise of an appropriate balance of skills, experience and knowledge to adapt to changing circumstances and discharge their responsibilities effectively. A direct inclusion of CSR-relevant experience, expertise, competence and reputation on the boards provide valuable perspectives on sustainability matters in corporate performance and CSR reporting (Mallin and Michelon, 2011; Carpenter and Westphal, 2001). Such presence inadvertently warrants an active incorporation of the CSR agenda into the strategic policies and decisions of companies. This study believes the overall proportion of board of directors with CSR-relevant experience is imperative to the level of CSR disclosure. An improved CSR governance and disclosure practices is achievable with the inputs from all directors during board-level strategic planning. The independence of the directors is irrelevant in considering the boards' advocacy towards CSR activities (Ratna et al., 2016; Gul and Leong, 2004; Kassinis and Vafeas, 2002). For this study, the presence of CSR-relevant board experience is determined from the corporate profiles of the board of directors. Active experience, assignment and participation in CSR-related are inferred from the directors' biographic descriptions provided in the annual report. The following hypothesis is postulated:

H1(UK/Malaysia): The level of CSR disclosure is positively associated with a CSR relevant board experience. 


\section{Company size}

Grounded on the association of social disclosure with political visibility, Belkaoui and Karpik (1989) posit a positive association between company size and CSR disclosure. Given the scale of operations and relatively greater economic and social influence, larger companies are often exposed to recurrent public visibility from the media (Fortainer et al., 2011; Gallo and Jones Christensen, 2011; Brammer and Pavelin, 2008). Empirical studies have substantiated that larger companies tend to disclose higher levels of public information readily to ease informational and political costs associated with information asymmetry (Gamerschlag et al., 2011; Chih et al., 2009; LaFond and Watts, 2008; Reverte, 2008; Cormier and Magnan, 2003). With increased public visibility, the likelihood of companies to use a formal channel to communicate CSR activities and improve their corporate image and legitimacy increases equitably (Haniffa and Cooke, 2005). Based on substantial unanimities to reason size as a CSR indicator, company size is predicted to have a positive relationship with the amount of CSR disclosure. For this study, sampled companies will represent the constituents of the largest market capitalisation from the national equity indices of FTSE Bursa Malaysia KLCI and FTSE 100. Using the natural logarithm of total assets of the companies (Lan et al, 2013), it is hypothesised that:

H2 (UK/Malaysia): The level of CSR disclosure is positively associated with company size.

\section{Profitability}

The disclosure of sustainability reporting is dependent on the adequacy of funding made available to companies. Generally, companies have limited available resources to respond to a wide range of stakeholder concerns. Profitable companies are more financially-abled to report socially responsible behaviours than companies with weaker financial performance (Reverte, 2008; Udayasankar, 2008; Campbell, 2007; Haniffa and Cooke, 2005). Two common financial performance indicators typically employed to measure a company's profitability are the return on equity (ROE) and return on assets (ROA). In review, although ROE inherently does not consider the financial risk of leveraging, it is relatively more stable than ROA in comparatively representing the true profitability of companies' performance quality. A higher level of disclosure to correspond with the managerial motivation to assert a company's favourable ROE with executive competencies and to progress managerial compensations (Lan et al., 2013; Gamerschlag et al., 2011). Since leverage will be analysed as a variable independently, this study will observe ROE as the representative determinant for profitability on CSR disclosure levels in maximising shareholder value. For these reasons, the following hypothesis is proposed:

\section{H3(UK/Malaysia): The level of CSR disclosure is positively associated with profitability.}

\section{Financial leverage}

Studies have indicated that a highly leveraged capital structure with substantial debt financing is synonymously associative to a higher level of information disclosure on account of a more demanding debt covenant and contracting cost between the company and its debt suppliers (Broberg et al., 2010; Mohd Ali et al., 2009). Managers are predisposed to disclose more information voluntarily to justify their financial position and project a positive socially responsible image to stakeholders (Cormier and Magnan, 2003). The likelihood for 
companies to disclose supplementary CSR information voluntarily increases to moderate the cost of information asymmetry and to lower the cost of capital (Jagd, 2015; Lan et al., 2013). Nevertheless, Giannarakis (2014) and Reverte (2008) reason an inverse effect of leverage on disclosure levels. A high level of restrictive debt covenants in debt agreements comprehensibly reduces the need for additional disclosure in annual reports (Eng and Mak, 2003). Owing to a higher level of insolvency and debt-servicing obligations, companies are unwilling to incur extraordinary costs to invest in non-value creating CSR activities on CSR disclosure (Barnea and Rubin, 2010). Similarly, findings from Haniffa and Cooke (2005) demonstrated the irrelevance of debt financing structure on CSR disclosures in Malaysia. Using the ratio of total debt to total assets to confirm the implication of leverage on CSR disclosures, the study hypothesises:

H4(UK/Malaysia): The level of CSR disclosure is positively associated with leverage in capital structure.

\section{RESEARCH METHOD}

\section{Sample and data}

For comparative purpose of this study, a purposive sampling strategy is employed on the constituents from the FTSE 100 Index and FTSE Bursa Malaysia KLCI across ten key industries as classified in the FTSE Industry Classification Benchmark (ICB). The sampled constituents for each index represent the top 30 companies by market capitalisation on the Bursa Malaysia and the London Stock Exchange as at June 2014 (FTSE Group, 2014).

Sustainability reports are expected to include the required specific standard disclosures prepared 'in accordance' with the G4 Sustainability Reporting Guidelines regardless of the size, sector or location. This study will only consider electronic and web-based annual reports (both integrated and separated) provided proactively in English on the companies' websites with a reporting period ending between 30 June 2012 and 31 March 2013 as at May 2014. The defined reporting period is to allow a better comprehension on the current standing of the sampled reports prior to the revised G4 framework. Table 1 and 2 represent the subdivided constituents sampled for both countries.

Table 1. FTSE Bursa Malaysia KLCI constituents

\begin{tabular}{llc}
\hline Constituent & ICB Subsector & Rank \\
\hline 0001 Oil \& Gas & & 11 \\
Petronas Gas Bhd & 0533 Exploration \& Production & 25 \\
Petronas Dagangan Bhd & 0537 Integrated Oil \& Gas & 13 \\
SapuraKencana Petroleum & 0573 Oil Equipment \& Services & \\
& & 9 \\
1000 Basic Materials & & \\
Petronas Chemicals Group Bhd & 1353 Commodity Chemicals & 6 \\
2000 Industrials & & 20 \\
Sime Darby Bhd & 2727 Diversified Industrials \\
MISC Bhd & 2773 Marine Transportation & 10 \\
3000 Consumer Goods & & 14 \\
IOI Corporation Bhd & 3573 Farming, Fishing \& Plantations & 24 \\
Kuala Lumpur Kepong Bhd & 3573 Farming, Fishing \& Plantations & 26 \\
Felda Global Ventures Holdings & 3573 Farming, Fishing \& Plantations & 21 \\
UMW Holdings & 3353 Automobiles &
\end{tabular}




\section{Health Care}

IHH Healthcare

\section{Consumer Services}

Genting Group

Genting Malaysia Bhd

Astro Malaysia Holdings

5753 Hotels

5753 Hotels

5553 Broadcasting \& Entertainment

6000 Telecommunications

Axiata Group Bhd

Digi.com

Maxis Berhad

Telekom Malaysia Bhd

6575 Mobile Telecommunications

6575 Mobile Telecommunications

6575 Mobile Telecommunications

6535 Fixed Line Telecommunications

\section{Utilities}

Tenaga Nasional

7537 Alternative Electricity

7575 Multi-utilities

8000 Financials

Public Bank BHD

8355 Banks

8355 Banks

8355 Banks

8355 Banks

8355 Banks

8355 Banks

8355 Banks

8633 Real Estate Holding \& Development

Croup Holding

Hong Leong Bank

RHB Capital

Hong Leong Financial Group

KLCC Prop\&Reits-Stapled Sec

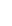

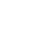

9000 Technology

Table 2. FTSE 100 constituents

\begin{tabular}{|c|c|c|}
\hline Constituent & ICB Subsector & Rank \\
\hline \multicolumn{3}{|l|}{0001 Oil \& Gas } \\
\hline $\mathrm{BP}$ & 0537 Integrated Oil \& Gas & 2 \\
\hline Royal Dutch Shell PLC & 0537 Integrated Oil \& Gas & 3 \\
\hline BG Group & 0537 Integrated Oil \& Gas & 11 \\
\hline \multicolumn{3}{|l|}{1000 Basic Materials } \\
\hline Rio Tinto & 1775 General Mining & 9 \\
\hline BHP Billiton & 1775 General Mining & 10 \\
\hline Glencore Xstrata & 1775 General Mining & 19 \\
\hline Anglo American & 1775 General Mining & 25 \\
\hline \multicolumn{3}{|l|}{2000 Industrials } \\
\hline Rolls-Royce Holdings & 2713 Aerospace & 24 \\
\hline \multicolumn{3}{|l|}{3000 Consumer Goods } \\
\hline British American Tobacco (UK) & 3785 Tobacco & 5 \\
\hline Imperial Tobacco Group & 3785 Tobacco & 23 \\
\hline SAB Miller & 3533 Brewers & 20 \\
\hline Diageo & 3535 Distillers and Vintners & 8 \\
\hline Unilever & 3577 Food Products & 16 \\
\hline Reckitt Benckiser Group & 3724 Nondurable Household Products & 15 \\
\hline \multicolumn{3}{|l|}{4000 Health Care } \\
\hline GlaxoSmithKline & 4577 Pharmaceuticals & 4 \\
\hline AstraZeneca & 4577 Pharmaceuticals & 7 \\
\hline Shire & 4577 Pharmaceuticals & 26 \\
\hline \multicolumn{3}{|l|}{5000 Consumer Services } \\
\hline Tesco & 5337 Food Retailers and Wholesalers & 22 \\
\hline WPP & 5555 Media Agencies & 28 \\
\hline Compass Group & 5757 Restaurants and Bars & 29 \\
\hline
\end{tabular}




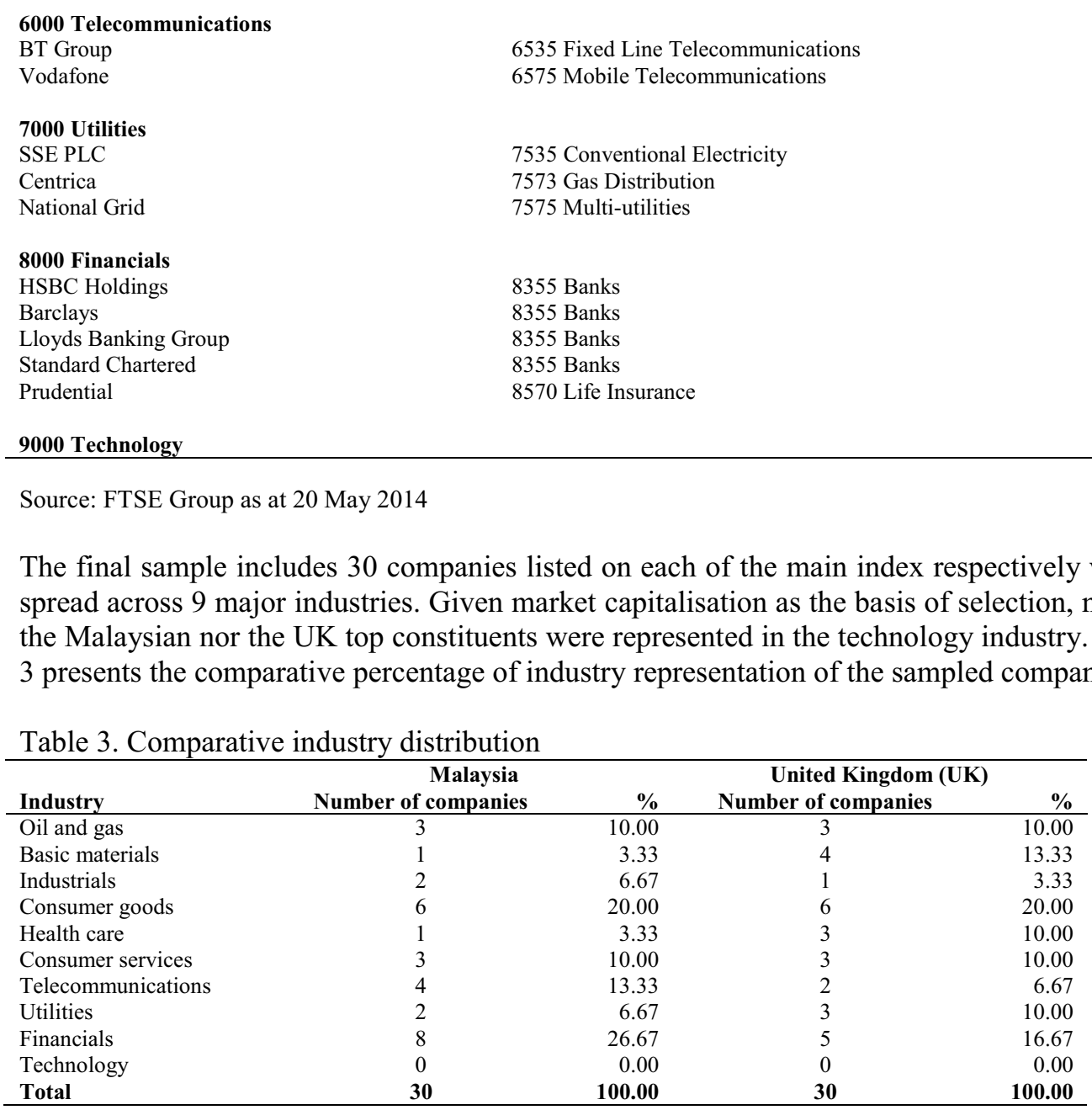

\section{CSR construction and measures}

For the first phase of the empirical study, a content analysis is applied to all 60 sampled annual reports to address cross-market similarities and differences in CSR disclosure. The context-sensitive abductive inferencing from content analysis allows a reliable and significantly meaningful informational representation of large volumes of data (Krippendorff, 1980). Thus, content analysis serves as an evocative gauge on the significance of the CSR agenda to companies. By replicating on past studies, this index study attempts to quantify specific CSR information observable in the sampled reports to examine the extent of various items' disclosures.

As stipulated in the Guidelines, the three main indicators analysed in this study are the economic, social and environmental dimensions of CSR disclosures. An aggregate measure of the quantity of disclosure for each indicator within the sustainability reports was constructed using the binary coding system. Inferred meanings from written words, sentences or paragraphs form the coding base for the disclosure indices for a more complete and meaningful dataset for subsequent analysis (Milne and Adler, 1999; Gray et al., 1995). The 
coding indices are validly and reliably derived from the latest core sustainability indicators outlined in the G4 Sustainability Reporting Guidelines.

In analysing the CSR information content in the sampled reports, the PDF reader's word count function was used (Gamerschlag et al, 2011). The total quantity of CSR disclosures (TQ ${ }_{\text {CSR }}$ ) from the analysed reports is represented by the average summative amount of the relative total scores awarded for the economic (ECN), environmental (ENV) and social (SOC) indicators:

$$
\mathrm{TQ}_{\mathrm{CSR}}(\mathrm{UK} / \mathrm{Malaysia})=\mathrm{SCORE}_{\mathrm{ECN}}+\mathrm{SCORE}_{\mathrm{ENV}}+\mathrm{SCORE}_{\mathrm{SOC}}
$$

whereby ECN demonstrates the capital flow and economic impact of the company on its stakeholders and economic system; ENV on impacts relating to operational inputs and outputs on living and non-living natural systems; and SOC on the operational impact on the social systems.

The derived indicators used in this study are presented in Table 4. There are 14 indicators representative of the ECN dimension, 25 indicators for ENV and 38 indicators for SOC.

Table 4. Content analysis indicators

\begin{tabular}{|c|c|c|}
\hline $\begin{array}{l}\text { Specific Standard Disclosures } \\
\text { Economic: } 14 \text { indicators }\end{array}$ & Environment:25indicators & \\
\hline Economic performance & Water & Awards \\
\hline Financial performance & Effluent and waste & Biodiversity \\
\hline Market presence & Spills & Environmental impacts \\
\hline Defined pension obligations & Greenhouse gas (GHG) & Conservation \\
\hline Tax relief, credits and subsidies & Hazardous waste & \\
\hline Financial assistance and incentive & Discharge & \\
\hline Risk management & Recycle & \\
\hline Awards & Reclaim & \\
\hline Government grants & Restore & \\
\hline Procurement practices & Reuse & \\
\hline Domestic job support & Recovery & \\
\hline Infrastructure development & Composting & \\
\hline \multirow{7}{*}{$\begin{array}{l}\text { Economic development } \\
\text { Research and } \\
\text { development }\end{array}$} & Preservation & \\
\hline & Disposal & \\
\hline & Emission treatment & \\
\hline & $\begin{array}{l}\text { Pollution control } \\
\text { Energy consumption and } \\
\text { saving }\end{array}$ & \\
\hline & Compliance and policies & \\
\hline & Protection & \\
\hline & $\begin{array}{l}\text { Environmental programmes } \\
\text { Costs (expenses) }\end{array}$ & \\
\hline
\end{tabular}


Social: 38 indicators

Employment

Remuneration

Trade / labour unions

Collective agreement / bargaining

Organisational communication

Discrimination

Child labour

Forced / compulsory labour

Work hazards

Diversity

Minorities

Equal opportunity

Human rights

Occupational safety

Occupational health

Employee benefits
Employee share purchase schemes

Retirement provision / plans

Insurance

Healthcare

Disability and invalidity coverage

Training, education and skills management

Performance / career development and reviews

Corruption

Personal gift

Anti-competitive / anti-trust behaviour

Product responsibility and labelling

Customer satisfaction

Customer health

Customer safety

Customer data and privacy

Community investment / programmes
Stakeholder engagement

Lobbying and advocacy (public policy)

Compliance

Fines / litigation / claims

Sanctions

Whistleblowing / ethics hotline / helpline

Source: Key themes derived from the GRI Specific Standard Disclosures and adapted to the original list used in Gamerschlag et al. (2011)

The indicators provide necessary information on the incorporation of the triple bottom line (TBL) accounting framework in a company, reflecting the performance or impacts of the ECN, ENV and SOC dimensions on stakeholders (GRI, 2013). It is essential to recognise the analysis of ECN's dimension as distinctive from fundamental financial and economic reporting examination. The reported ECN information entails concerns over organisational impact on stakeholders' economic conditions.

Adapting to the scoring measure used in Lan et al. (2013) and Botosan (1997), the relative degree of CSR disclosure for each respective indicator, $i$, is quantified as follows:

$$
\mathrm{SCORE}_{i}=\frac{\mathrm{DSCORE}^{i}}{\mathrm{MAXSCORE}} \times \frac{1}{3}
$$

In the second phase of the study, three statistical analysis methods were applied to test hypotheses H1 to H6 using the IBM Statistical Package for Social Sciences (SPSS) version 21 software. Table 5 summarises the examined variables.

Table 5. Summary of variables measures

\begin{tabular}{lll}
\hline \multicolumn{2}{c}{ Variables } & \multicolumn{1}{c}{ Measures } \\
\hline & Independent Variables & Percentage of CSR-relevant experience among board of directors \\
H1 & Board experience (EXP) & Natural log of total assets \\
H2 & Company size (SZE) & Return on equity (ROE) \\
H3 & Profitability (PRO) & Ratio of total debt to total assets \\
H4 & Financial leverage (LVG) & \\
& Dependent Variable &
\end{tabular}


The first statistical analysis method applies descriptive statistics analysis to measure the variables' mean, standard deviation, total quantity of CSR disclosures, and other relevant descriptions of the data. Using Pearson's correlation analysis, the relationships between the independent and dependent variables were measured. This analysis measures the strength of the relationships between the drivers of sustainability reporting and the amount of disclosed CSR information. The indicative results specify the significant values and the strength of the relationship is indicated within the range of \pm 1 ; a strong correlation as between \pm 0.7 to 0.9 ; a moderate correlation as between \pm 0.4 to 0.6 ; and, a weak correlation as between \pm 0.1 to 0.3 (Dancey \& Reidy, 2004).

In the second method, the Spearman's rank correlation is used to identify the association of each individual independent variable with the total CSR disclosure (TQCSR) for its monotonic function. The Spearman's rank correlation coefficient analysis is not a measure for linear relationship between the independent and dependent variables. Spearman's coefficient is denoted by $r_{s}$ and is constrained by the limit of $-1 \leq r_{s} \leq 1$. This nonparametric correlation analysis permits two variables to be compared for a monotonic function with no requirement of normality for the variables to be measured. A coefficient is considered significant if the pvalue is less than 0.05 (1-tailed). The strength of the monotonic relationship between two variables is measured as either very weak ( 0.00 to 0.19$)$; weak $(0.20$ to 0.39$)$; moderate $(0.40$ to 0.59 ); strong (0.60 to 0.79 ); or, very strong (0.80 to 1.0) (Hauke and Kossowski, 2011). Assumption was made that there was evidence of non-linearity for secondary data. For these reasons, hypotheses $\mathrm{H} 1$ to $\mathrm{H} 4$ were tested using Spearman's rank correlation coefficient to confirm the association between the total CSR disclosure and the independent variables.

Lastly, in substantiating the variation in company-specific characteristics on CSR disclosure levels, the multiple linear regressions (MLR) analysis is applied to identify which predictors or independent variables (IVs) of the company-specific characteristics predict the outcome of the CSR disclosure levels. Accordingly, to determine the multiple effects of the independent variables on the dependent variable, the proposed multiple regression equation is surmised as:

$$
\text { TQCSR (UK/Malaysia) }=\alpha+\beta_{1} \mathrm{EXP}+\beta_{2} \mathrm{SIZE}+\beta_{3} \mathrm{PRO}+\beta_{4} \mathrm{LVG}+\varepsilon
$$

where the DV for this study is the total CSR disclosure (TQCSR) of the sampled reports subjected to the IVs consisting of the proportion of the board of directors with CSR-relevant experience; the total assets owned by the companies; the profitability and adequacy of funds available; and the leverage in capital structure.

Specifics for the variables are sourced from the provided reports (both the annual and sustainability reports). In analysing the variables, this study adopted measurements from Lan et al. (2013) and Gamerschlag et al. (2011). All figures are logged at the respective companies' reported year-ends.

\section{RESULTS}

\section{Data analysis}

\section{Content analysis}

Based on the data compiled for SCORE $\mathrm{ECN}_{\mathrm{E}}$ SCORE $\mathrm{SEVN}_{\mathrm{N}}$ and SCORESOC, the maximum binary scores for the economic, environment and social indicator were 14, 25 and 38 respectively. 
A comparative review of the total CSR disclosure, TQCSR for both countries showed variations across different industries. In UK, the highest score of TQCSR was reported by Diageo (Consumer Goods) at 0.96, while the lowest was at 0.48 from Shire (Health Care). In Malaysia, Petronas Chemicals Group Bhd (Oil \& Gas) reported the highest score at 0.69, while Hong Leong Bank (Financials) scored lowest at 0.37. Diageo's near-perfection score was considerably influenced by the company's explicit public assertion and commitment with the GRI guidelines and UN Global Compact (UNGC) to a full reporting practice in their annual audited report.

Expectedly, companies in the UK have a higher economic, environment and social SCORE than in Malaysia (see Table 6). The average total CSR disclosure TQCSR scores for UK and Malaysia were 0.76 and 0.52 respectively. On closer observation on the specific (i.e. economic, environmental, and social) TQCSR scores, it shows a well-balanced information disclosure in all three CSR indicators for the UK companies. For the Malaysia sample, the results demonstrated a bias in CSR disclosure efforts on the ECN dimension. Seemingly, the companies emphasised more on the economic aspect of the CSR reporting than the environmental and social disclosures. The worst disclosure SCORE for the Malaysian companies was at 0.13 from Petronas Gas Bhd (Oil \& Gas) for the ENV indicator.

Table 6. Average total CSR disclosure (AVGTQCSR)

\begin{tabular}{|c|c|c|c|c|}
\hline & AVGSUM $_{\text {ECN }}$ & AVGSUMENV $_{\text {EN }}$ & AVGSCORE & AVGTQCSR \\
\hline$U K$ & 0.28 & 0.21 & 0.27 & 0.76 \\
\hline Malaysia & 0.24 & 0.13 & 0.15 & 0.52 \\
\hline
\end{tabular}

The data from the first phase of the study are subjected to further analysis in the next phase to test the developed hypotheses.

\section{Descriptive statistic}

The results presented in Table 7 shows the overall descriptive statistics for the independent and dependent variables' means and standard deviations (SD).

Table 7. Descriptive statistics

\begin{tabular}{|c|c|c|c|c|}
\hline & \multicolumn{2}{|c|}{ United Kingdom (UK) } & \multicolumn{2}{|c|}{ Malaysia } \\
\hline & Mean & Std. Deviation & Mean & Std. Deviation \\
\hline ECN & 0.2820 & 0.03089 & 0.2373 & 0.05065 \\
\hline ENV & 0.2090 & 0.06830 & 0.1287 & 0.06213 \\
\hline SOC & 0.2747 & 0.02980 & 0.1483 & 0.03445 \\
\hline TQCSR & 0.7650 & 0.10608 & 0.5153 & 0.09325 \\
\hline EXP & 31.9520 & 16.72012 & 20.8223 & 13.61406 \\
\hline SZE & 25.0303 & 1.49238 & 24.4350 & 1.72155 \\
\hline PRO & 17.4533 & 16.76181 & 35.8813 & $85.87423^{*}$ \\
\hline LVG & 0.6710 & 0.19308 & 0.5823 & 0.28000 \\
\hline
\end{tabular}

In Table 8, the values in the Pearson's correlation matrix indicate some significant linear relationships for the independent and dependent variable for both countries. In UK, only the 
relationship for PRO and SZE was identified with a moderate negative correlation strength of -0.441 . For the Malaysian model, moderate association strengths were observed for LVG and EXP, and, PRO and SZE, of -0.493 , -and -0.409 respectively.

Table 8. Pearson's correlation matrix

\begin{tabular}{|c|c|c|c|c|}
\hline \multicolumn{5}{|c|}{ UK - Correlations } \\
\hline EXPUK & 1.000 & & & \\
\hline SZEUK & -0.169 & 1.000 & & \\
\hline PROUK & -0.047 & $-0.441 * *$ & 1.000 & \\
\hline LVGUK & -0.116 & $0.354 *$ & $-0.391^{*}$ & 1.000 \\
\hline \multicolumn{5}{|c|}{ Malaysia - Correlations } \\
\hline EXPM & 1.000 & & & \\
\hline SZEM & 0.011 & 1.000 & & \\
\hline PROM & -0.140 & $-0.409 *$ & 1.000 & \\
\hline LVGM & $-0.493 * *$ & 0.172 & 0.294 & 1.000 \\
\hline $\begin{array}{r}\text { Note: } * * \\
*\end{array}$ & $\begin{array}{l}\text { is signific } \\
\text { is signific }\end{array}$ & $\begin{array}{l}\text { he } 0.01 \text { lev } \\
\text { he } 0.05 \text { lev }\end{array}$ & $\begin{array}{l}\text { ailed) } \\
\text { ailed) }\end{array}$ & \\
\hline
\end{tabular}

\section{Hypotheses testing}

\section{Spearman's rank correlation coefficient analysis}

The results for hypotheses $\mathrm{H} 1$ to $\mathrm{H} 4$ for UK companies indicated only financial leverage (LVG) was significant for Spearman's rank correlation coefficient $\left[r_{s}=-0.345, n=30, p<.05\right.$ (1-tailed)]. This suggests that H4 is supported (see Table 9). This means the level of CSR disclosure is negatively associated with leverage in capital structure. Other hypotheses were not supported.

In the Malaysian model, H1 to H3 were supported. H1, which indicates directors' CSRrelevant experience, has a significant Spearman's coefficient of $r_{s}=0.413[n=30, p<.05]$; while H2, for company size, presents with an $r_{s}=-0.315[n=30, p<.05]$; and H3, for profitability with the $\mathrm{r}_{\mathrm{s}}=0.372[\mathrm{n}=30, \mathrm{p}<.05]$. H2 interestingly shows a reversed relationship. H4 was not supported. Only $\mathrm{H} 1$ has a moderate strength of monotonic relationship between the dependent and independent variables. Other significant variables reflect weak relationships.

Table 9. Spearman's correlation matrix of variables

\begin{tabular}{|c|c|c|c|c|c|}
\hline \multicolumn{6}{|c|}{ UK - Correlations } \\
\hline TQCSRUK & 1.000 & & & & \\
\hline EXPUK & -0.062 & 1.000 & & & \\
\hline SZEUK & 0.127 & -0.092 & 1.000 & & \\
\hline PROUK & 0.086 & -0.070 & -0.527 & 1.000 & \\
\hline LVGUK & $-0.345^{*}$ & -0.074 & 0.117 & -0.257 & 1.000 \\
\hline \multicolumn{6}{|c|}{ Malaysia-Correlations } \\
\hline EXPM & $0.413^{*}$ & 1.000 & & & \\
\hline SZEM & $-0.315^{*}$ & -0.187 & 1.000 & & \\
\hline PROM & $0.372 *$ & -0.143 & -0.414 & 1.000 & \\
\hline LVGM & -0.185 & -0.446 & 0.291 & 0.351 & 1.000 \\
\hline
\end{tabular}

Ordinary regression analysis (OLS) assumptions test

When performing OLS, assumptions test is important to ensure non-normality of the variables. These can be determined by calculating the z-values the variables' skewness and 
kurtosis. If the z-values are within \pm 1.96 for skewness and kurtosis, it indicates some form of normality. This can be obtained by dividing skewness and standard error of skewness. Similarly, this applies to measuring kurtosis (Jöreskog, 1999). The result for the UK companies showed only one variable, PRO, has violated the rule of $\mathrm{z}$-values. For the Malaysian companies, three variables (EXP, SZE, PRO) have high skewness and kurtosis values (see Table 10). These variables were transformed to $\log (10)$ in the SPSS command icon to adjust the skewness and kurtosis to near normality for analysis (Field, 2009; Bowerman \& O'Connell, 1990). Upon transformation of the non-normality variables, the standard deviation spreads were acceptable (see Table 11). Comparison of the two countries using MLR indicated no violations from the assumptions tests.

Table 10. Assumptions test

\begin{tabular}{|c|c|c|c|c|c|}
\hline UK & TQCSRUK & EXPUK & SZEUK & PROUK & LVGUK \\
\hline Skewness & -0.466 & 0.462 & 0.782 & -5.401 & -0.157 \\
\hline $\begin{array}{l}\text { Std. Error of } \\
\text { Skewness }\end{array}$ & 0.427 & 0.427 & 0.427 & 0.427 & 0.427 \\
\hline Z-Value $( \pm 1.96)$ & -0.981 & 1.082 & 1.831 & 12.649 & 0.368 \\
\hline Kurtosis & 0.485 & -0.708 & 0.026 & 29.437 & 0.345 \\
\hline $\begin{array}{l}\text { Std. Error of } \\
\text { Kurtosis }\end{array}$ & 0.833 & 0.833 & 0.833 & 0.833 & 0.833 \\
\hline Z-Value $( \pm 1.96)$ & 0.582 & 0.85 & 0.031 & 35.34 & 0.414 \\
\hline Malaysia & TQCSRM & EXPM & SZEM & PROM & LVGM \\
\hline Skewness & 0.168 & 1.215 & 1.109 & 4.604 & -0.208 \\
\hline $\begin{array}{l}\text { Std. Error of } \\
\text { Skewness }\end{array}$ & 0.427 & 0.427 & 0.427 & 0.427 & 0.427 \\
\hline Z-Value $( \pm 1.96)$ & 0.930 & 2.845 & 2.597 & 10.780 & -0.487 \\
\hline Kurtosis & -1.129 & 1.9171 & 2.818 & 22.458 & -1.121 \\
\hline $\begin{array}{l}\text { Std. Error of } \\
\text { Kurtosis }\end{array}$ & 0.833 & 0.833 & 0.833 & 0.833 & 0.833 \\
\hline Z-Value ( \pm 1.96$)$ & -1.355 & 2.301 & 3.383 & 26.96 & 1.346 \\
\hline
\end{tabular}

Table 11. Descriptive statistics - non-normality statistics adjusted for log (10)

\begin{tabular}{lccccc}
\hline & UK & & \multicolumn{3}{c}{ Malaysia } \\
\hline \multirow{3}{*}{ PROUKLOG } & Mean & Std. Deviation & & Mean & Std. Deviation \\
& 0.6422 & 1.27453 & EXPMLOG & 1.2472 & 0.24323 \\
& & SZEMLOG & 1.3870 & 0.02976 \\
& & & PROMLOG & 1.1390 & 0.67033 \\
\hline
\end{tabular}

The results in Table 12 on regression coefficients for UK companies shows SZE was significant with unstandardized coefficient $B$ at $0.045(\mathrm{p}<0.029)$. For Malaysia, only EXP was significant with a $B$ of $0.179(\mathrm{p}<0.026)$. Other variables did not predict the total CSR disclosure. The VIF measures for collinearity in the data were within the limit of $<10$. Similarly, the Durbin-Watson test for correlated residuals was within the limit of 0 to 4 . In Table 13, the model summary for UK has an $\mathrm{R}^{2}$ value of 0.284 and for Malaysia, an $\mathrm{R}^{2}$ value of 0.315 . The $\mathrm{R}^{2}$ value for UK indicated that $28.4 \%$ of the variance in dependent variable can be explained by the predictor variables; and for Malaysia, at $31.5 \%$. 
Table 12. Regression coefficients

\begin{tabular}{|c|c|c|c|c|c|c|c|c|c|}
\hline \multirow[b]{3}{*}{ Model } & \multicolumn{7}{|c|}{ UK - Coefficients } & & \\
\hline & \multicolumn{2}{|c|}{$\begin{array}{l}\text { Unstandardised } \\
\text { coefficients }\end{array}$} & \multirow{2}{*}{$\begin{array}{c}\text { Standardised } \\
\text { coefficients } \\
\beta\end{array}$} & \multirow[t]{2}{*}{$t$} & \multirow[t]{2}{*}{ Sig. } & \multicolumn{2}{|c|}{$\begin{array}{c}95.0 \% \\
\text { confidence } \\
\text { interval for } \beta\end{array}$} & \multicolumn{2}{|c|}{$\begin{array}{l}\text { Collinearity } \\
\text { statistics }\end{array}$} \\
\hline & $B$ & $\begin{array}{l}\text { Std. } \\
\text { error }\end{array}$ & & & & $\begin{array}{l}\text { Lower } \\
\text { bound }\end{array}$ & $\begin{array}{l}\text { Upper } \\
\text { bound }\end{array}$ & Tolerance & $V I F$ \\
\hline (Constant) & -0.309 & 0.504 & & -0.935 & 0.360 & -1.764 & 0.666 & & \\
\hline EXPUK & 0.000 & 0.001 & 0.002 & 0.012 & 0.991 & -0.002 & 0.002 & 0.916 & 1.092 \\
\hline SZEUK & 0.045 & 0.019 & 0.634 & 2.331 & 0.029 & 0.005 & 0.085 & 0.421 & 2.373 \\
\hline \multirow{4}{*}{$\begin{array}{l}\text { PROUKLOG } \\
\text { LVGUK }\end{array}$} & 0.000 & 0.017 & 0.003 & 0.014 & 0.989 & -0.034 & 0.035 & 0.781 & 1.281 \\
\hline & -0.062 & 0.147 & -0.113 & -0.422 & 0.677 & -0.366 & 0.242 & 0.434 & 2.302 \\
\hline & \multicolumn{7}{|c|}{ Malaysia - Coefficients } & & \\
\hline & \multicolumn{2}{|c|}{$\begin{array}{l}\text { Unstandardised } \\
\text { coefficients }\end{array}$} & $\begin{array}{l}\text { Standardised } \\
\text { coefficients }\end{array}$ & \multirow[t]{2}{*}{$t$} & \multirow[t]{2}{*}{ Sig. } & \multicolumn{2}{|c|}{$\begin{array}{c}95.0 \% \\
\text { confidence } \\
\text { interval for } \beta\end{array}$} & \multicolumn{2}{|c|}{$\begin{array}{l}\text { Collinearity } \\
\text { statistics }\end{array}$} \\
\hline Model & $B$ & $\begin{array}{l}\text { Std. } \\
\text { error }\end{array}$ & $\beta$ & & & $\begin{array}{l}\text { Lower } \\
\text { bound }\end{array}$ & $\begin{array}{l}\text { Upper } \\
\text { bound }\end{array}$ & Tolerance & $V I F$ \\
\hline (Constant) & -0.235 & 2.197 & & -0.107 & 0.916 & -4.775 & 4.313 & & \\
\hline EXPMLOG & 0.179 & 0.075 & 0.466 & 2.379 & 0.026 & 0.023 & 0.334 & 0.775 & 1.291 \\
\hline SZEMLOG & 0.339 & 1.547 & 0.109 & 0.221 & 0.827 & -2.857 & 3.540 & 0.122 & 8.180 \\
\hline PROMLOG & 0.071 & 0.069 & 0.510 & 1.035 & 0.311 & 0.071 & 0.213 & 0.123 & 8.150 \\
\hline LVGM & -0.038 & 0.114 & -0.113 & -0.329 & 0.745 & -0.274 & 0.199 & 0.253 & 3.960 \\
\hline
\end{tabular}

Table 13. Model summary for the UK and Malaysia

\begin{tabular}{|c|c|c|c|c|c|c|c|c|}
\hline \multicolumn{9}{|c|}{ UK - Model summary } \\
\hline \multirow[t]{2}{*}{$R$} & \multirow[t]{2}{*}{$\overline{R^{2}}$} & \multirow{2}{*}{$\begin{array}{c}\text { Adjusted } \\
R^{2}\end{array}$} & \multirow{2}{*}{$\begin{array}{c}\text { Std. Error } \\
\text { of the } \\
\text { Estimate }\end{array}$} & \multicolumn{4}{|c|}{ Change Statistics } & \multirow[b]{2}{*}{$\begin{array}{l}\text { Durbin- } \\
\text { Watson }\end{array}$} \\
\hline & & & & $\begin{array}{c}R^{2} \\
\text { Change }\end{array}$ & $\begin{array}{c}F \\
\text { Change }\end{array}$ & $d f 1 \quad d f 2$ & $\begin{array}{l}\text { Sig. } F \\
\text { Change }\end{array}$ & \\
\hline 0.533 & 0.284 & 0.097 & 0.10089 & 0.284 & 1.519 & $6 \quad 23$ & 0.216 & 1.784 \\
\hline \multicolumn{9}{|c|}{ Malaysia - Model summary } \\
\hline \multirow[t]{2}{*}{$R$} & \multirow[t]{2}{*}{$\overline{R^{2}}$} & \multirow{2}{*}{$\begin{array}{c}\text { Adjusted } \\
R^{2}\end{array}$} & \multirow{2}{*}{$\begin{array}{l}\text { Std. Error } \\
\text { of the } \\
\text { Estimate }\end{array}$} & \multicolumn{4}{|c|}{ Change Statistics } & \multirow{2}{*}{$\begin{array}{l}\text { Durbin- } \\
\text { Watson }\end{array}$} \\
\hline & & & & $\begin{array}{c}R^{2} \\
\text { Change }\end{array}$ & $\begin{array}{c}F \\
\text { Change }\end{array}$ & $d f 1 \quad d f 2$ & $\begin{array}{c}\text { Sig. } F \\
\text { Change }\end{array}$ & \\
\hline 0.561 & 0.315 & 0.137 & 0.08664 & 0.315 & 1.765 & 23 & 0.151 & 1.093 \\
\hline
\end{tabular}

Therefore, the model equations for the two countries can be presented as follow:

$\mathrm{TQ}_{\mathrm{CSR}(\mathrm{UK})}=\quad-0.309+0.002 \mathrm{EXP}+0.634 \mathrm{SZE}+0.003 \mathrm{PRO}-0.113 \mathrm{LVG}+\varepsilon$

$\mathrm{TQ}_{\mathrm{CSR} \text { (Malaysia) }}=-0.235+0.466 \mathrm{EXP}+0.109 \mathrm{SZE}+0.510 \mathrm{PRO}-0.113 \mathrm{LVG}+\varepsilon$

The ANOVA results indicate whether the overall models did predict the total CSR disclosure. In the UK model, the ANOVA has $\mathrm{F}(6,0.234)=1.510[\mathrm{~F}$ (df effect, df error) $=$ F-value $]$ with $\mathrm{p}=0.219$; and in Malaysia, $\mathrm{F}(6,0.173)=1.765, \mathrm{p}=0.151$. The non-significant values of the 
ANOVA indicated the two regression models overall did not predict the total CSR disclosure (TQCSR). However, the non-normality variables from the UK and Malaysia data may have affected the p-values of the F-test as this test is sensitive to non-normality variables (Markowski and Markowski, 1990). Moreover, the ANOVA results from MLR do not indicate the individual contribution of the variables (Field, 2009). Since this exploratory study aims to review the contribution of specific regression coefficient, the non-significant value in $\mathrm{F}$ becomes secondary (Dallal, 2000).

\section{Summary of hypotheses testing}

The overall hypotheses results are summarised in Table 14. Results with significant values of less than 0.05 are supported and vice versa.

Table 14. Hypotheses results

\begin{tabular}{cccc}
\hline \multicolumn{2}{c}{ Hypotheses } & United Kingdom (UK) & Malaysia \\
\hline H1 & TQCSR vs EXP & Not supported & Supported \\
H2 & TQCSR vs SZE & Not supported & Supported \\
H3 & TQCSR vs PRO & Not supported & Supported \\
H4 & TQCSR vs LVG & Supported & Not supported \\
Multiple regression results & Supported: SZE & Supported: EXP \\
\hline
\end{tabular}

\section{FINDINGS AND DISCUSSION}

This study aims to compare and assess the effects of company-specific variables on the level of CSR disclosure in United Kingdom (UK) and Malaysia's public-listed companies.

Using Spearman's correlations analysis, the total CSR disclosure TQCSR for the UK sample was found to be negatively associated with financial leverage $(\mathrm{H} 4 \mathrm{UK})$. The result suggests that an increase in leverage would reduce the extent of CSR disclosure. This finding is consistent with recent studies by Giannarakis (2014) and reaffirms earlier literatures from Barnea and Rubin (2010) and Haniffa and Cooke (2005). Interestingly, the size of company (H2 Malaysia) was found to have a negative association with total CSR disclosure. This finding contrasted with previous studies whereby larger firms with increased public visibility tend to invest more in CSR reporting activities (Lan et al., 2013; Gamerschlag et al., 2011; Udayasankar, 2008).

Comparatively, the TQCSR in Malaysian companies was positively associated with the board of directors' CSR-relevant experience ( $\left.\mathrm{H} 1_{\text {Malaysia }}\right)$ and company's profitability ( $\left.\mathrm{H} 3_{\text {Malaysia }}\right)$. A higher balance of board of directors with the appropriate CSR knowledge and experience are able to provide better advice and advocacy on matters pertaining to corporate sustainability agendas (Financial Reporting Council, 2012; Securities Commission Malaysia, 2012; Carpenter and Westphal, 2001). Referring to Table 6, evidences from the descriptive statistics on average TQCSR (UK/Malaysia) proves an overall better quality of CSR disclosure in the UK than in Malaysia. A higher mean value for UK companies than Malaysia indicates a larger composition of board members with CSR-relevant experiences. This implicates the importance of board experiences in CSR and this factor could contribute to the academic knowledge for sustainability reporting. 
In terms of profitability, this finding is consistent with most preceding studies. The results consolidate with Haniffa and Cooke (2005) s' associative study on CSR disclosures and financial performance of Malaysian companies. In signalling the discretionary non-financial commitments through reporting, companies instinctively reduces potential agency costs and gains long-term competitive advantage over their future stock liquidity (Setyroni and Ishak 2012; Cormier and Magnan, 2003).

Based on the multiple linear regression (MLR) models, the size (SZE) of company in Malaysia is found to be significant in affecting the overall level of CSR disclosure. This relationship affirmed past studies on the explanatory factor of SZE as a consistent predictor for TQCSR in both developed and developing countries (Giannarakis, 2014; Gallo and Jones Christensen, 2011; Amran et al., 2007; Haniffa and Cooke, 2005).

As a final point, in the Malaysian model, relevant CSR board experience (EXP) is a key determinant for CSR-disclosure levels. The significant EXP variable is also found to be consistent with the Spearman's correlation coefficient. While board of directors may recognise the strategic value of sustainability reporting in reducing agency costs, the incorporation of social and environmental priorities onto the core business function requires adequate CSR-relevant board experience to effectively manage CSR governance.These results undoubtedly confirmed the importance of a composition of board members with CSRrelevant experiences or skills on sustainability reporting.

\section{Limitation and future studies}

The limitations from this research are associated with industry classification and sample size. The incentive to disclose CSR information is driven by the associated cost of lobbying and stakeholder pressure. Companies from industries with a higher level of impactful environmental and social involvements are inclined to have a higher level of CSR disclosures. Due to the time constraints of the research period, a complete analysis on all industries from the entire list of companies to distinguish the effect of industrial differences is not feasible.

In regards to the limitation concerning sample size, this study was conducted using a purposive sampling strategy whereby 30 secondary datasets from the FTSE 100 Index and FTSE Bursa Malaysia KLCI each were selected for analyses. The 30 samples from each index with $95 \%$ confidence level have a confidence interval (margin of error) of \pm 15.05 . This means the sample answer is true between $34.95 \%$ [50-15.05] and 65.05\% [50+15.05] (Creative Research System, 2012). For this reason, a larger sample size from each country would possibly lower confidence level and yield a higher R2 values and identify more determinants influencing CSR disclosure levels. At this level of exploratory study, the findings are not generalisable. Future research should increase the sample sizes from each country to 60 for more reassuring analyses to compare the results.

\section{Potential implications}

\section{Implication for practice}

Since the board of directors' experience was found to be the key predictor for total CSR disclosure levels, companies should attempt to increase the board's composition with 
directors having CSR-relevant experiences or skills. Merely officiating CSR events or receiving CSR awards would not lead the board members' awareness on the importance of sustainability reporting. In order to endorse the importance of CSR accountability explicitly, companies could also assign a specific appointment of at least one director in the board to be responsible in CSR activities or trained in CSR-related programmes. Additionally, the appointed board member should oversee the content of the annual CSR voluntary disclosure in annual or sustainability reports.

\section{Implication for methodology}

This study has provided useful results by comparing both the developed and developing countries' sustainability reporting practices in the top 30 publicly listed companies. It provides a direct comparison in terms of the quantity and quality of CSR disclosure in both the integrated or separated sustainability reports. The comparative method allows company representatives in both countries to improve on their reporting weaknesses. Academic researchers who are interested in comparative studies would find this research thoughtprovoking and possibly extend the analysis further.

\section{CONCLUSION}

This research conclusively affirms the existence of specific sustainability reporting drivers in motivating the commitment on voluntary corporate social responsibility (CSR) disclosure practices for companies in the United Kingdom (UK) and Malaysia. Results from the study empirically highlighted substantially higher total quantity of CSR disclosure (TQCSR) for companies in the UK than in Malaysia. More importantly, this study has established board experience (EXP) in CSR initiatives as a pivotal determinant in the variation of results on sustainability reporting levels. Malaysian companies have much to emulate from the UK companies to improve on the CSR disclosure levels in their annual (both integrated and separated) reports.

As globalisation and trade propagates continuously, organisational stakeholders will increasingly place importance on the non-financial operational impact from companies. Sustainability reporting is no longer merely viewed as a tool to satisfy the companies' moral obligations to stakeholders. Efforts to adopt and institutionalise international sustainability reporting frameworks from the likes of the Global Reporting Initiative (GRI) or UN Global Compact helps companies to improve their operating efficiencies and CSR stewardship. In order to gain competitive advantage and achieve long-term corporate sustainability, strong affirmations from companies, particularly those from the emerging markets should exploit the adoption and gradual integration of sustainably reporting into their reporting efforts.

\section{REFERENCES}

Amran, A., Lim, L.L. and Sofri, Y. (2007). A Study of Corporate Philanthropic Traits among Major Malaysian Corporations, Social Responsibility Journal, 3 (4), 21 - 30

Anderson, A. and Gupta, P.P. (2009). A cross-country comparison of corporate governance and firm performance: Do financial structure and the legal system matter? Journal of Contemporary Accounting \& Economics, 5, 61-69. 
Association of Chartered Certified Accountants (ACCA) (2014). Report of the judges, ACCA Malaysia Sustainability Reporting Awards (MaSRA). Malaysia: ACCA.

Barnea, A. and Rubin, A., (2010). Corporate social responsibility as a conflict between shareholders. Journal of Business Ethics, 97, 71-86.

Belkaoui, A. and Karpik, P.G., (1989). Determinants of the corporate decision to disclose social information. Accounting, Auditing and Accountability Journal, 2 (1), 36-51.

Botosan, C.A. (1997). Disclosure level and the cost of equity capital. Accounting Review, 72 (3), 323-50.

Bowerman, B.L. and O'Connell, R.T. (1990). Liner statistical models: An applied approach ( $2^{\text {nd }}$ ed.), Belmont, CA: Duxbury.

Brammer, S. and Pavelin, S. (2008). Factors influencing the quality of corporate environmental disclosure. Business Strategy and the Environment, 17 (2), 120-36.

Broberg, P., Tagesson, T. and Collin, S., (2010). What explains variation in voluntary disclosure? A study of the annual reports of corporations listed on the Stockholm Stock Exchange. Journal of Management \& Governance, 14, 351-77.

Campbell, J.L., (2007). Why would corporations behave in socially responsible ways? An institutional theory of corporate social responsibility. Academy of Management Review, 32 (3), 946-67.

Carpenter, M.A. and Westphal, J.D. (2001), "The strategic context of external network ties: Examining the impact of director appointments on board involvement in strategic decision making", Academy of Management Journal, 44 (4), 639-60.

Chambers, E., Chapple, W., Moon, J. and Sullivan, M. (2003). CSR in Asia: A seven country study of CSR website reporting. International Centre for Corporate Social Responsibility (ICCSR) Research Paper Series, 09-2003. Nottingham: Nottingham University Business School.

Chih, H.L., Chih, H.H. and Chih, T.Z. (2009). On the determinants of corporate social responsibility: International evidence on the financial industry. Journal of Business Ethics, 93, 115-35.

Cormier, D., Magnan, M. (2003). Environmental reporting management: a continental European perspective. Journal of Accounting and Public Policy, 22, 43-62.

Creative Research System (2012). The Survey System: Sample size calculator. Available at: $<$ http://www.surveysystem.com/sscalc.htm $>$ [Accessed 31 august 2014].

Dallal, G.E. (2000), How to Read the Output From Multiple Linear Regression Analyses.

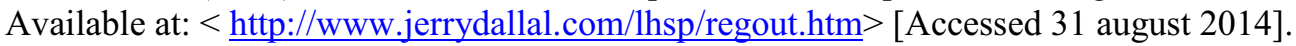

Dancey, C., \& Reidy, J. (2004). Statistics without maths for psychology: Using SPSS for Windows, London: Prentice Hall. 
Eng, L.L. and Mak Y.T. (2003). Corporate governance and voluntary disclosure. Journal of Accounting \& Public Policy, 22, 325-345.

Field, A., (2009). Discovery statistics using SPSS ( $3^{\text {rd }}$ ed.), SAGE Publications Ltd. London.

Financial Reporting Council (2012). UK Corporate Governance Code. Available at: http://www.slc.co.uk/media/78872/uk-corporate-governance-code-september-2012.pdf [Accessed 18 June 2014]

Fortainer, F., Kolk, A., Pinkse, J. (2011). Harmonization in CSR reporting: MNEs and global CSR standards. Management International Review, 51, 665-96.

Freeman, R.E., Moutchnik, A., 2013. Stakeholder management and CSR: questions and answers. UmweltWirtschaftsForum: uwf, 21, pp.5-9. Available at: 10.1007/s00550-013-0266$\underline{3}$ [Accessed 18 June 2014].

FTSE Group (2014a). FTSE 100 UK Index Series Quarterly Data - May 2014. Available at: http://www.ftse.com/analytics/factsheets/Home/ConstituentsWeights [Accessed 15 June 2014]

FTSE Group (2014b). FTSE Bursa Malaysia KLCI Index Series Review Changes Overview - June 2014. Available at:

http://www.ftse.com/analytics/factsheets/Home/ConstituentsWeights [Accessed 15 June 2014]

Gallo, P.J., Jones Christensen, L. (2011). Firm size matters: an empirical investigation of organizational size and ownership on sustainability-related behaviors. Business \& Society, 50, 315-49.

Gamerschlag, R., Moller, K. and Verbeeten, F. (2011). Determinants of voluntary CSR disclosure: Empirical evidence from Germany. Review of Managerial Science, 5 (2-3), 23362.

Global Reporting Initiative (GRI), 2013. G4 Sustainability Guidelines. Available at: https://www.globalreporting.org/resourcelibrary/GRIG4-Part1-Reporting-Principles-andStandard-Disclosures.pdf [Accessed 7 April 2014].

Gray, R., Kouhy, R. and Lavers, S. (1995). Methodological Themes: Constructing a research database of social and environmental reporting by UK companies. Accounting, Auditing \& Accountability Journal, 8 (2), 78-101.

GRI Reporting Framework, 2013. Available at: https://www.globalreporting.org/reporting/reporting-framework-overview/Pages/default.aspx [Accessed 14 March 2014]

Giannarakis, G. (2014) "Corporate governance and financial characteristic effects on the extent of corporate social responsibility disclosure", Social Responsibility Journal, 10 (4), 569-590. 
Gul, F., A. and Leong, S. (2004). Board leadership, outside directors' expertise and voluntary corporate disclosures. Journal of Accounting and Public Policy, 23 (5), 351-79.

Haniffa, R., Cooke, T.E. (2005). The impact of culture and governance on corporate social reporting. Journal of Accounting and Public Policy, 24, 391-430.

Hauke, J. and Kossowski, T. (2011). Comparison of values of Pearson's and Spearman's correlation coefficients on the same sets of data. Quaestiones Geographicae, 30 (2), 87-93.

Jöreskog, K., G. (1999). Formula for Skewness and Kurtosis. Available at: http://www.ssicentral.com/lisrel/techdocs/kurtosis.pdf [Accessed 27 August 2014].

Kassinis, G. and Vafeas, N. (2002). Corporate boards and outside stakeholders as determinants of environmental litigation. Strategic Management Journal, 23 (5), 399-414.

Krippendorff, K. (1980). Content analysis: An introduction to its methodology. Beverly Hills: Sage Publications.

Kytle, B. and Ruggie, J. R. (2005). Corporate social responsibility as risk management: A model for multinationals. Corporate Social Responsibility Initiative Working Paper 10. Cambridge: John F. Kennedy School of Government, Harvard University.

LaFond, R. and Watts, R.L. (2008). The information role of conservatism. Accounting Review, 83 (2), 447-78.

La Porta, R., Lopez-de-Silanes, F. and Shleifer, A. (2008). The Economic Consequences of Legal Origins. Journal of Economic Literature, 46 (2), 285-332. Available at: http://www.aeaweb.org/articles.php?doi-10.1257/jel.46.2.285 [Accessed 4 July 2014]

Lan, Y., Wang, L. and Zhang, X., (2013). Determinants and features of voluntary disclosure in the Chinese stock market. China Journal of Accounting Research, 6, 265-85.

Markowski, C.A. and Markowski, E.P. (1990). Conditions for the Effectiveness of a Preliminary Test of Variance, The American Statisticia, Vol. 44, No. 4 (Nov.), 322-326

Mat Nor, F., Mohd. Shariff, F. and Ibrahim, I. (2010). The effects of concentrated ownership on the performance of the firm: Do external shareholdings and board structure matter? Jurnal Pengurusan, 30, 93-102.

Milne, M.J. and Adler, R.W. (1999). Exploring the reliability of social and environmental disclosures content analysis. Accounting, Auditing and Accountability Journal, 12 (2), 23756.

Mohd Ali, M., Ibrahim, M.K., Mohammad, R., Zain, M.M. and Alwi, M.R. (2009). Malaysia: Value relevance of accounting numbers. In Idowu, S.O. \& Filho, W.L. (Eds.), Global Practices of Corporate Social Responsibility, 201-230. Berlin: Springer.

Orlitzky, M., Schmidt, F.L. and Rynes, S.L. (2003). Corporate social and financial performance: A meta-analysis. Organization Studies, 24 (3), 403-441. 
Ratna, N., Grantley, T., Rusminm R., Greg T., Bikram, C. (2016). Factors determining social and environmental reporting by Indian textile and apparel firms: a test of legitimacy theory. Social Responsibility Journal, 12 (1), 167-89.

Reverte, C. (2009). Determinants of corporate social responsibility disclosure ratings by Spanish listed firms. Journal of Business Ethics, 88, 351-66.

Securities Commission (SC) Malaysia (2012). Malaysian Code on Corporate Governance (MCGG). Available at:

$<$ http://www.mia.org.my/new/downloads/circularsandresources/circulars/2012/21/MCCG 20 12.pdf $>$ [Accessed 18 June 2014]

Siegel and Vitaliano (2007). An empirical analysis of the strategic use of corporate social responsibility. Journal of Economics \& Management Strategy, 16 (3), 773-92.

Udayasankar, K. (2008). Corporate social responsibility and firm size. Journal of Business Ethics, 83, 167-75.

United Nations Environment Programme (UNEP), 2013. Carrots and Sticks: Sustainability reporting policies worldwide - Today's best practice, tomorrow's trends. Available at: $<$ https://www.globalreporting.org/resourcelibrary/Carrots-and-Sticks.pdf $>$ [Accessed 14 March 2014] 